42. Requests for reprints should be addressed to: Liisa Rovamo, M.D., Children's Hospital University of Helsinki, 00290 Helsinki 29. Finland.

43. This research was supported by the Foundation for Pediatric Research, Hilma and Heikki Honkanen's Foundation. Foundation of Nutritional Research. Finnish Academy, Finnish Foundation for Culture, Huhtamäki OY, Leiras
Pharmaceuticals, Sigrid Juselius Foundation, and Nordisk Insulinfond. 44. We thank Sirkka Runeberg, Paula Teräväinen, and Hannele Hilden for their skillful technical assistance.

45. Received for publication September 27, 1983

\title{
Diamine Oxidase and Disaccharidase Activities in Small Intestinal Biopsies of Children
}

\author{
P. FORGET ${ }^{(8)}$ C. GRANDFILS, J. L. VAN CUTSEM, AND G. DANDRIFOSSE \\ Department of Pediatrics (P. F., J. L. V.C.) and Department of General and Comparative Biochemistry (C. G., \\ G. D.), Liege University, Liège, Belgium
}

\section{Summary}

A relationship between disaccharidase and diamine oxidase (DAO) activities was looked for by measuring these enzyme activities in histologically normal small intestinal biopsies of 18 children. The range for disaccharidase activities expressed in $\mathrm{U}$ $\mathrm{g}^{-1}$ wet weight was $0.1-5.7,7.1-36.7$, and $2.3-8.5$ for lactase, maltase, and sucrase, respectively. The range for DAO activities expressed in $\mathrm{nmol} \mathrm{h}{ }^{-1} \mathrm{~g}^{-1}$ wet weight was 202-974. Significant correlations were found between disaccharidase and DAO activities (lactase versus DAO: $n=17, r=0.80, P<0.001$; maltase versus DAO: $n=18, r=0.70, P<0.001$; sucrase versus DAO: $n=18, r=0.55, P<0.05$ ). Our results further support the hypothesis that DAO is a marker of small intestinal functional integrity in children.

\section{Abbreviation}

\section{DAO, diamine oxidase}

DAO is an enzyme showing a high activity in small intestinal mucosal extracts from humans and other mammalian species (4). The enzyme is localized in the cytosol fraction of mature villous enterocytes (1). The physiological function of this enzyme in the intestinal mucosa is still a matter of discussion (1). DAO activity is measurable not only in mucosal extracts but also in serum. A correlation between serum and ileal activities has been shown to exist in the rat (4).

It has been suggested that the presence of this enzyme activity in the small intestinal mucosa would reflect the presence of mature functional villous enterocytes (4). In the rat, DAO and disaccharidase activities follow a parallel increase during both intestinal maturation and recovery after intestinal injury (4). If, in children, both disaccharidase and diamine oxidase activities are characteristics of functional villous enterocytes, a correlation between these activities could exist. The present study is the first one which looks for a possible relationship between intestinal DAO and disaccharidase activities in children with a histologically normal mucosa.

\section{PATIENTS AND METHODS}

Eighteen children were studied. Age, sex, and clinical data are shown in Table 1.

A small intestinal biopsy of our patients was taken in order to exclude an enteropathy as a possible cause of their clinical symptoms. Informed consent was obtained for each patient. Only the results obtained in children showing no or minimal histological biopsy changes were included in this study. Biopsies were generally obtained from the distal duodenum by endoscopy (G1P, P3, Olympus). Biopsies from other intestinal parts were taken when necessary. No complications were encountered. Duodenal biopsies were wrapped in parafilm and frozen $\left(-20^{\circ} \mathrm{C}\right)$. Analysis was performed within 2 weeks.

Methods. Measurement of disaccharidase activities. The activity of lactase (EC 3.2.1.23), maltase (EC 3.2.1.20) and sucrase (EC 3.2.1.48) was measured according to the method of Dahlqvist (3). The specific activities were expressed in units $\mathrm{g}^{-1}$ wet weight of mucosa.

Measurement of DAO activities. The activity of DAO (EC 1.4.3.6) was estimated by a method close to the radiometric technique described by Okuyama and Kobayashi (6). In this method, $\left[{ }^{3} \mathrm{H}\right]$ putrescine is used as substrate. The reaction product $\left(\Delta_{1}\right.$-pyrroline) is extracted in toluene and its radioactivity is estimated by using a scintillation spectrometer (Packard, 3255).

Details were as follows. Each small intestinal biopsy was extracted in distilled water $(1 \mathrm{mg} / 200 \mu \mathrm{l})$ by using a Potter homogenizer (equipped with a glass pestle and tube). The extract was used without further treatment for the measurement of the disaccharidase activities. It was diluted 20 times in phosphate buffer $(0.1 \mathrm{M}, \mathrm{pH} 7.4)$ for the estimation of the DAO activity.

$\left[{ }^{3} \mathrm{H}\right]$ Putrescine was purchased from New England Nuclear Co. It had a specific radioactivity of $40.5 \mathrm{Ci} \mathrm{mmol}^{-1}$. Before utilization, it was mixed with unlabeled putrescine in order to reach a specific radioactivity of approximately $1 \mathrm{Ci} \mathrm{mmol}{ }^{-1}$. To determine the DAO activity, $50 \mu \mathrm{l}$ of the homogenate was mixed with $50 \mu \mathrm{l}$ of putrescine (160 pmol, yielding approximately 280,000 (pm).

The mixture was incubated at $37^{\circ} \mathrm{C}$ for variable periods $(0,10$, 20 , and $30 \mathrm{~min}$ ). The reaction was stopped by the addition of 10 
Table 1. Clinical details and intestinal specific activities of disaccharidases and of diamine oxidase*

\begin{tabular}{|c|c|c|c|c|c|c|c|c|}
\hline \multirow[b]{2}{*}{ Case } & \multirow{2}{*}{$\begin{array}{c}\text { Age } \\
\text { (years) }\end{array}$} & \multirow[b]{2}{*}{ Sex } & \multirow{2}{*}{$\begin{array}{c}\text { Clinical } \\
\text { presentation }\end{array}$} & \multirow{2}{*}{$\begin{array}{c}\text { Small bowel } \\
\text { histology }\end{array}$} & \multicolumn{3}{|c|}{$\begin{array}{l}\text { Disaccharidase activities } \\
\left(\mathrm{U} \mathrm{g}^{-1} \text { wet weight }\right)\end{array}$} & \multirow{2}{*}{$\begin{array}{c}\text { Diamine Oxidase } \\
\text { Activity } \\
\text { (nmol h }{ }^{-1} \mathrm{~g}^{-1} \text { wet } \\
\text { weight) }\end{array}$} \\
\hline & & & & & Lactase & Maltase & Sucrase & \\
\hline 1 & 3 & $\mathrm{M}$ & Bronchitis & Normal & 5.7 & 36.7 & 6.0 & 902 \\
\hline 2 & 2 & M & Vomiting & Normal & 3.2 & 16.7 & 5.7 & 833 \\
\hline 3 & 5 & $\mathrm{M}$ & Bronchitis & Normal & 1.2 & 9.6 & 2.5 & 543 \\
\hline 4 & 0.5 & $\mathrm{M}$ & Chronic diarrhea & Min. charges & 3.8 & 25.6 & 8.5 & 974 \\
\hline 5 & 0.2 & $\mathrm{M}$ & Vomiting & Min. charges & 2.3 & 14.6 & 3.9 & 602 \\
\hline 6 & 6 & $\mathrm{~F}$ & Bronchitis & Normal & 1.1 & 13.8 & 4.4 & 649 \\
\hline 7 & 1.2 & $\mathrm{~F}$ & FTT & Normal & 1.9 & 14.3 & 5.2 & 324 \\
\hline 8 & 0.9 & M & Vomiting & Normal & 2.0 & 10.7 & 4.3 & 414 \\
\hline 9 & 4 & M & Bronchitis & Min. changes & 0.5 & 6.9 & 2.3 & 202 \\
\hline 10 & 2.5 & $F$ & FTT & Normal & 1.6 & 11.7 & 2.9 & 300 \\
\hline 11 & 1.8 & M & FTT & Normal & 1.7 & 18.0 & 5.1 & 244 \\
\hline 12 & 5 & $\mathrm{~F}$ & Bronchitis & Normal & 1.9 & 22.5 & 7.8 & 436 \\
\hline 13 & 2 & $\mathrm{~F}$ & FTT & Normal & 1.1 & 10.0 & 3.1 & 223 \\
\hline 14 & 0.8 & M & Diarrhea & Normal & 0.8 & 7.1 & 2.0 & 348 \\
\hline 15 & 0.5 & M & Vomiting & Normal & 0.1 & 21.1 & 2.4 & 597 \\
\hline 16 & 0.4 & $\mathrm{~F}$ & Vomiting & Normal & 1.6 & 16.6 & 5.0 & 463 \\
\hline 17 & 5 & $\mathrm{~F}$ & Bronchitis & Normal & 0.2 & 8.1 & 2.7 & 277 \\
\hline 18 & 1 & $\mathrm{M}$ & FTT & Normal & 1.3 & 14.6 & 4.3 & 363 \\
\hline
\end{tabular}

* Min. changes, slight inflammatory changes in the lamina propria; FTT, failure to thrive; other explanations, see text.

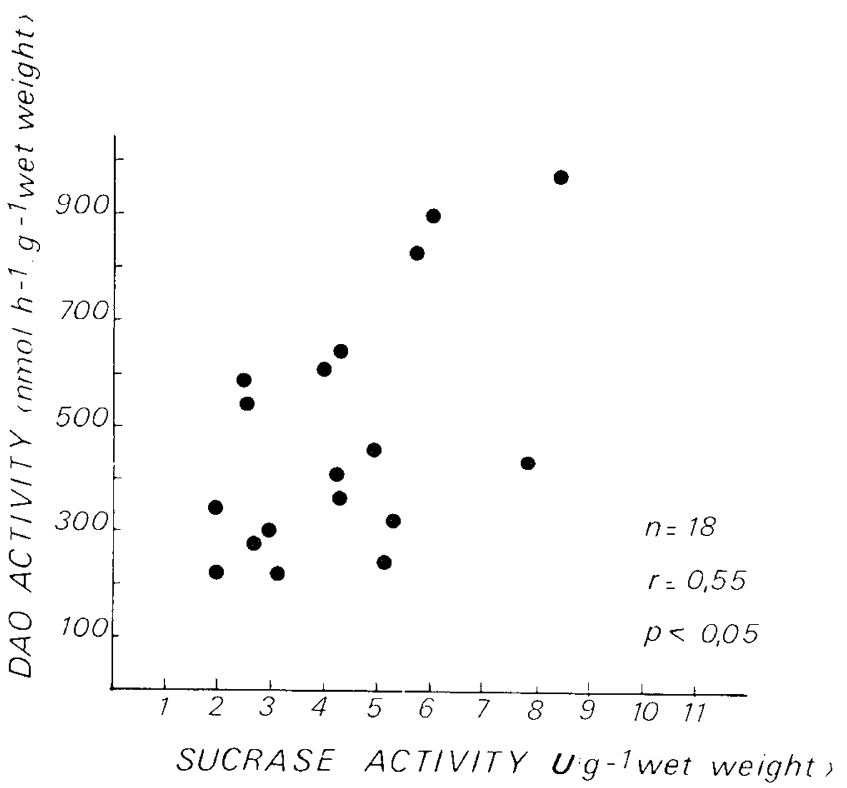

Fig. 1. Relationship between small intestinal mucosal sucrase and diamine oxidase activities.

$\mu \mathrm{l}$ of aminoguanidine $\left(10^{-4} \mathrm{M}\right) .50 \mu \mathrm{l}$ of a saturated bicarbonate solution was then added to each tube in order to improve the toluene extractability (6). The toluene extraction was performed twice by using $500 \mu \mathrm{l}$ of the organic solvent and by allowing the watery phase to freeze. $800 \mu \mathrm{l}$ of the mixed toluene phases was poured into counting vials containing $6 \mathrm{ml}$ of Lumagel. $50 \mu \mathrm{l}$ of substrate solution added in Lumagel served as standard. Each determination of DAO activity was performed in duplicate or in triplicate. Mucosal specific activity was calculated and expressed in $\mathrm{nmol} \mathrm{h}^{-1} \mathrm{~g}^{-1}$ wet weight.

Activities were shown to be proportional to time and quantity of enzyme. Activities were thereafter measured routinely at 20 min with occasional checks of the time-activity relationship.

\section{RESULTS}

Results of DAO, lactase, maltase, and sucrase activities are shown in Table 1 . The ranges for disaccharidase activities ex-

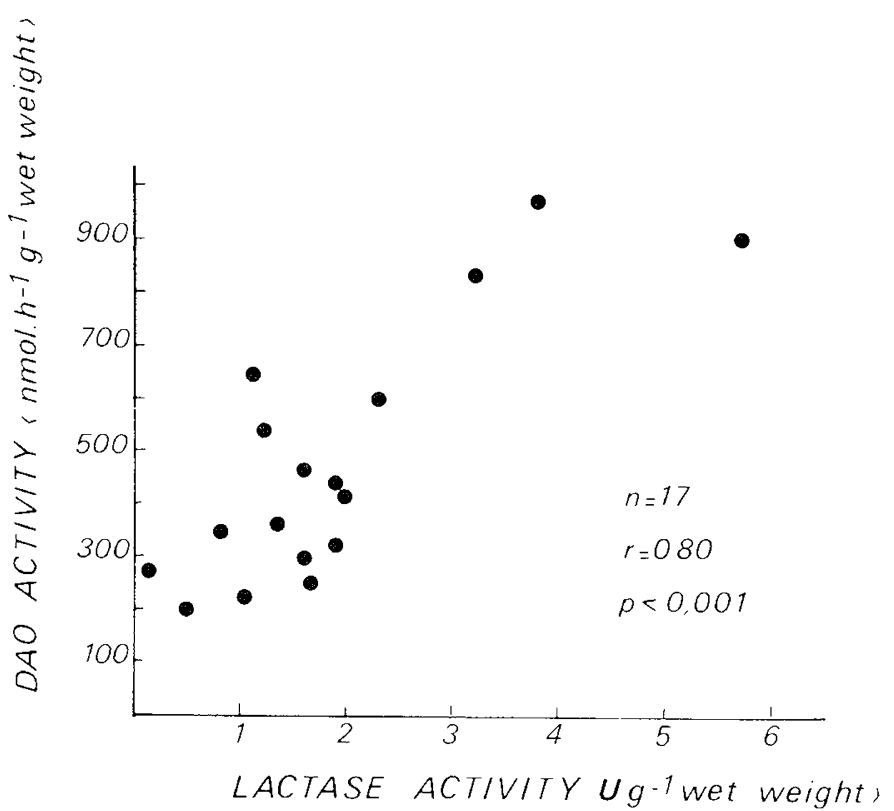

Fig. 2. Relationship between small intestinal mucosal lactase and diamine oxidase activities.

pressed in $\mathrm{U} \mathrm{g}^{-1}$ wet weight were $0.1-5.7,7.1-36.7$, and 2.3-8.5 for lactase, maltase, and sucrase, respectively. The range for DAO activities expressed in $\mathrm{nmol} \mathrm{h} \mathrm{h}^{-1} \mathrm{~g}^{-1}$ wet weight was 202974.

Relationships between DAO on the one hand and sucrase, lactase, or maltase activities on the other hand are shown in Figures 1, 2, and 3. Significant correlations were found between disaccharidase and DAO activities (lactase versus DAO: $n=17$, $r=0.80, P<0.001$; maltase versus DAO: $n=18, r=0.70, P<$ 0.001 ; sucrase versus DAO: $n=18, r=0.55, P<0.05$ ).

\section{DISCUSSION}

The observations we made and which are presented in Table 1 indicate that DAO and disaccharidase activities are easily measured in endoscopically obtained duodenal biopsies in children. However, our values of disaccharidase activities are some- 


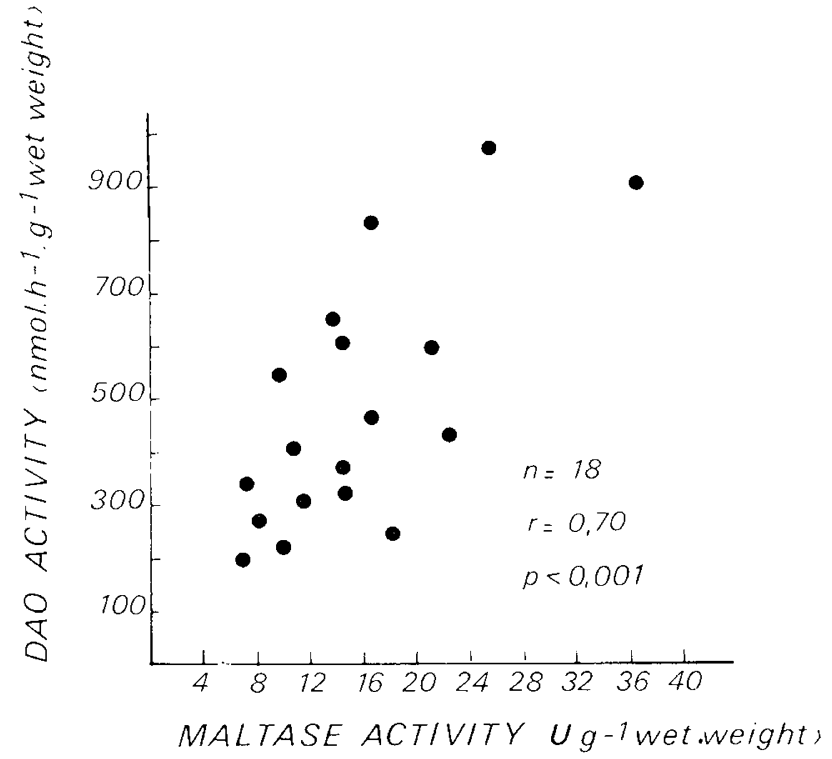

Fig. 3. Relationship between small intestinal mucosal maltase and diamine oxidase activities.

what $( \pm 30 \%)$ lower than those reported by Newcomer and McGill (5). This difference could result from the fact that our biopsies were taken from the distal duodenum, whereas small bowel biopsies are classically obtained from the jejunum by making use of different types of biopsy capsules. It has indeed been proved that duodenal disaccharidase activities are about $40 \%$ lower when compared to jejunal ones (2). Moreover, it should be stressed that our patients, although showing a normal mucosa at histology, might have had a slight, histologically undetectable, mucosal damage, resulting in a slight decrease of enzymatic activities.

The disaccharidase activities in our patients showed wide variations, the highest being 10 times higher than the lowest. These large variations are not related to the age or the sex of the children and are in agreement with literature data (5). Diamine oxidase activities showed less variation, the highest activity being about 4 times higher than the lowest.

A significant relationship was found between all three disaccharidase activities and DAO activity. This relationship was found in spite of the fact that these enzymes have different localizations in the small intestinal mucosa: brush border for disaccharidase activities and cytosol fraction of enterocytes for DAO activities (1).

Our findings further support the hypothesis that DAO is a marker of small intestinal functional integrity (4). Further studies are in progress in order to investigate the relationship between mucosal and serum DAO activity. Such a correlation has been shown to exist in the rat (4). If this also applies to human, serum DAO might turn out to be a most useful tool in the diagnosis and management of various types of enteropathies in childhood.

\section{REFERENCES AND NOTES}

1. Baylin SB, Stevens SA, Shakir KMN 1978 Association of diamine oxidase and ornithine decarboxylase with maturing cells in rapidly proliferating epithelium. Biochim Biophys Acta 541:415

2. Bergoz R, Griessen M, Infante F, De Peyer R, Vallotton MC 1981 Significance of duodenal disaccharidases. Digestion 22:108

3. Dahlquist A 1964 Method for the assay of the intestinal disaccharidases. Anal Biochem 7:18

4. Luk GD, Bayless JM, Baylin SB 1980 Diamine oxidase (histaminase). A circulating marker for rat intestinal mucosal maturation and integrity. J Clin Invest 66:66

5. Newcomer AD, McGill DB 1967 Disaccharidase activity in the small intestine: prevalence of lactase deficiency in 100 healthy subjects. Gastroenterology 53:881

6. Okuyama T, Kobayashi Y 1961 Determination of diamine oxidase activity by liquid scintillation counting. Arch Biochem Biophys 95:242

7. This research was supported by a grant from Nutricia, The NetherlandsBelgium.

8. Requests for reprints should be addressed to: Dr. P. Forget, Department of Pediatrics, Liège University, 66, bd de la Constitution, 4020 Liège, Belgique. 9. Received for publication August 15, 1983.

10. Accepted for publication September 28, 1983 